Acta Regionalia et Environmentalica 1

Nitra, Slovaca Universitas Agriculturae Nitriae, 2015, pp. 25-29

\title{
SOCIO-ECONOMIC IMPORTANCE OF ASSOCIATED PLANT SPECIES IN SHORT ROTATION COPPICE PLANTATIONS
}

\author{
Michal BENIAK*, Michal ŽABKA
}

Slovak University of Agriculture in Nitra, Slovak Republic

\begin{abstract}
Many ecosystem services do not pass through markets. Therefore, the benefits which ecosystems provide to society are largely unrecorded. Fast-growing woody crops represent a quite new and still insufficiently explored ecosystem of agricultural land which has a potential to provide several utility functions. It may contribute to satisfaction of human needs and may enhance regional health. The goal of this paper was to detect the socio-economic importance of associated spontaneous vegetation in plantations of the energy crops (hybrids of the genera Salix) and to compare it with the socio-economic importance of adjacent permanently cultivated agricultural field. There was examined the therapeutic, melliferous, feed, allergenic and toxic potential of undergrowth for each experimental plot inside the SRC plantations. The research was carried out on the agricultural land formerly used for growing cereals and root crops - the research base Kolínany. Our results showed that energy plantation understoreys can be assumed to be the better option for contribution to the total socio-economic value of a region than agricultural fields.
\end{abstract}

Keywords: hybrids of the genera Salix, socio-economic importance, spontaneous vegetation, SRC plantations, utility functions

Biomass is one of the renewable energy sources already available for climate change mitigation. It is regarded a key option for reducing dependency on imported fuels in the EU (Berndes and Hansson, 2007). According to Rösch et al. (2013), short rotation coppices (SRC) are one option to enhance sustainable biomass production and to enlarge domestic wood resources. A large-scale shift from "conventional" arable crops to short rotation coppice plantations will have implications on a range of environmental issues, and large-scale implementation of those crops for bio-energy purposes makes sense only if they prove to reduce negative effects on the environment, especially when compared with other alternatives for reduction of fossil energy sources (Weih and Dimitriou, 2012).

To understand the implications of increased bioenergy production, it is important to recognize that the land used for energy cropping is a natural resource, comprising soil, minerals, water and biota (MA, 2005). As such, it plays an essential role in delivering valuable ecosystem services, such as supporting the cultivation of biomass for food, energy and other products, and regulating the environment, e.g. via water filtration or carbon sequestration. Communities also often attach considerable cultural and religious values to local landscapes (EEA, 2013). However, many ecosystem services do not pass through markets. The benefits they provide to society are largely unrecorded (Levy et al., 2005).

In the general classification of vegetation functions in the landscape, two basic groups of functions - ecological and social (or socio-economic) functions - were distinguished. Ecological functions are considered in systems of ecological relationships and they are important for the existence of natural ecosystems. Social functions of vegetation are considered in the system of social relationships. They are products of the society's needs and make use of the properties and effects of vegetation (Eliáš, 2010).

If SRC represent an environmentally sound and economically feasible option it may contribute to regional wealth. There is a hope that such plantings will create new areas for the agricultural business, agro-forestry, and induce social wealth (Köhn, 2009), support development of rural tourism and hunting (Mosquera-Losada et al., 2012), and also offer benefits such as the development of a new export industry and employment creation (especially in rural areas) (Berndes and Hansson, 2007).

Ecosystem services refer to the range of conditions and processes through which ecosystems, and the species that they contain, help sustain and fulfil human life (Daily, 1997). Various wild plants growing under energetic plantations contribute not only to the ecological sustainability of an ecosystem, but they are also important to some extent to fulfil the needs of the local people (Sangha and Jalota, 2005). Different functional groups of plants can be identified with positive (rare plants, medical and melliferous plants, edible plants, fodder, phytoremediation etc.) and negative impacts (source of crop weeds, invasive plants, competition, toxicity etc.) (Fehér et al., 2014). Maximum monetary value of energetic plantations undergrowth was marked for food, fodder, medicine and soil stability (Jalota et al., 2000). Reddersen (2001) assumes that willow plantations provide an ideal early nectar crop for honey bees and other beneficial insects. However, land's capacity to provide all these services depends on its management (EEA, 2013).

This paper presents an evaluation of socio-economic importance of SRC understorey vegetation (genus Salix), 
especially utility functions that relate to primary production of vascular plants. There are many other utility functions of vegetation e.g. soil stabilization, water filtration, aesthetic value of a plantation, which also contribute to the total socio-economic value of an ecosystem, which are not included in this study.

\section{Material and methods}

\section{Research area and experimental plots}

The experiment was carried out in the locality Kolínany, located $10 \mathrm{~km}$ northeast from the city of Nitra (GPS $-48^{\circ}$ $21^{\prime} 21^{\prime \prime} \mathrm{N}$ a $18^{\circ} 12^{\prime} 23^{\prime \prime} \mathrm{E}$ ). The average annual temperature of air is $10.2{ }^{\circ} \mathrm{C}$ and the average rainfall is $524.4 \mathrm{~mm}$ (SHMI, 2013). Cadastral area falls to the climatic region MT2 (temperate warm, slightly moist), with the sum of temperature $2200-2500{ }^{\circ} \mathrm{C}$, with a probability of dry growing season 15-30\% (Lapin et al., 2002). The territory belongs to the maize production area with flat terrain, with $87 \%$ of degree of plowing and $8 \%$ of permanent grassland (Špánik et al., 2000). Main soil unit at the research site is gleyic fluvisol, moderate soil located mostly in the alluvial plains of rivers with high level of groundwater (Linkeš et al., 1996). The average soil $\mathrm{pH}$ in the research site was 7.26 and the average percentage of humus content was $1.83 \%$ (Hauptvogl, 2011).

The research was conducted inside plantations of fastgrowing trees (genus Salix) during two growing seasons (from 12 ${ }^{\text {th }}$ of March 2013 until $6^{\text {th }}$ of November 2014). In the constant experimental plots, quantitative characteristics of phytocenoses were recorded in periodical two weeks intervals. This data were collected from the three plots allocated in the middle of willow plantations with extent of $24 \mathrm{~m}^{2}$, within three planted varieties of Swedish provenance of genus Salix - Gudrun, Inger, Tordis (surveys started at the beginning of the second year of their three-years harvest cycles, when canopy of energy trees was been highly developed). We also allocated one adjacent experimental plot with the same extend on agricultural field under regular cultivation (with the crop Cucurbita pepo in the first year and Triticum aestivum in the second year) in order to compare our data.

\section{Floristic assessment of vegetation and data analysis}

The abundance of taxa was evaluated by the BraunBlanquet scale (Braun-Blanquet, 1964), modified and expressed in percentage. The names of taxa were listed by Marhold and Hindák (1998). The persistence of species (persistence category by Jurko, 1990), which served as the basis for expressing the coefficient of species significance in the phytocenoses, was expressed. In order to investigate a level of melliferous, feed, therapeutic, allergenic and toxic importance of each surveyed understorey, a proper eco-value to the each found plant species was assigned (according to Jurko, 1990).

The melliferous importance, as well as feed and toxic importance, was calculated as the coefficient of species significance for the each plant species multiplied by the eco-value appertaining to the each found plant species.
Therefore, the total value of melliferous importance, as well as toxic importance, was obtained as the sum of these calculated values for each plant species. In case of feed importance, the total value was obtained as a difference between the sum of positive values and the sum of negative values for each plant species with specific feed potential (plant species that had a positive eco-value for feed potential and simultaneously also various eco-value for toxic potential e.g. Cirsium arvense, Ligustrum vulgare, Robinia pseudoacacia, were excluded from this calculation). The total therapeutic importance, and allergenic importance, was calculated as sum of the coefficient of species significance for the each plant species with various eco-values. Evaluation of vegetation from allergenic point of view was realized only for allergenic pollen plants.

\section{Results and discussion}

Our field surveys showed that experimental plots inside the energetic plantations had 1.30-1.56 times more plant species than experimental plot in agricultural field under regular cultivation. The trend that plant species number in SRC plantation is higher than in conventional agricultural fields was reported e.g. by Weih et al. (2003), Britt et al. (2007), Fry and Slater (2009) or Baum et al. (2009). Diverse plants perform different ecosystem functions which contribute to the sustainability of an ecosystem. Ecosystem functions performed by one species may be complementary to the other species (Tilman et al., 1997). Sanga and Jalota (2005) mentioned that various wild plants growing under plantations are also important as medicine and food/fodder. If phytodiversity of energy plantations understorey increase, we can assume that the total ability to provide ecosystem services and to contribute to sustainability of an ecosystem increases as well.

The most diverse experimental plot which we surveyed was plot located inside the variety Tordis. We found that $72.22 \%$ of its observed understorey species had the therapeutic potential (26 of the total 36 plant species). Likewise, the highest therapeutic importance (74.37) was noticed there. Understoreys of varieties Inger and Gudrun were characterized by the same number of species with various therapeutic eco-values (19 plant species). For the variety Inger, it represented $61.29 \%$ and for the variety Gudrun $63.33 \%$ of the total number of species in their understoreys. However, they evidently differed to each other in the total coefficient of species significance. We recorded the decrease of $41.36 \%$ for the variety Gudrun (50.44) compared with the variety Inger (86.01). The adjacent agricultural field was characterized by extremely low value of therapeutic importance (only 1.63) and also by low number of occurred plants with therapeutic potential (only 11 plant species), compared with all surveyed willow varieties (Figure 1).

The understorey of the variety Tordis was also characterized by the highest feed importance from all of the observed willow varieties (119.16), on the other hand, the percentage of plants with positive feed eco-value of the Tordis understorey was the lowest from the observed willow varieties (47.22\%; 17 plants with positive feed potential). The 


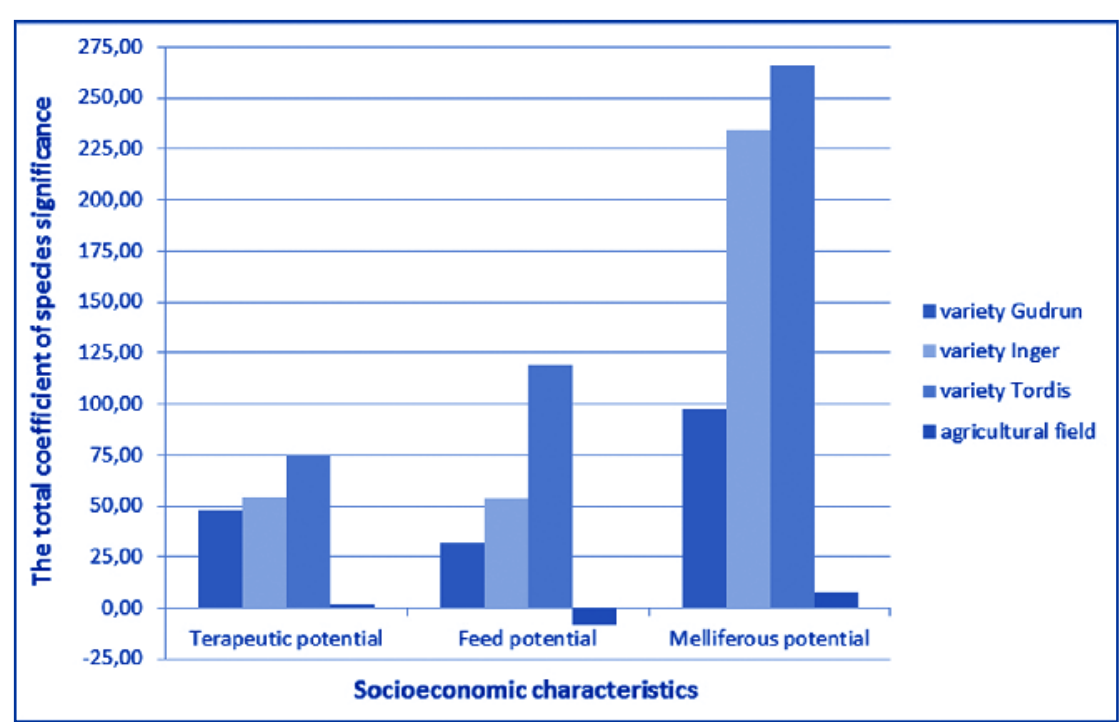

Figure 1 Socio-economic importance of characteristics that enhance ecosystem utility

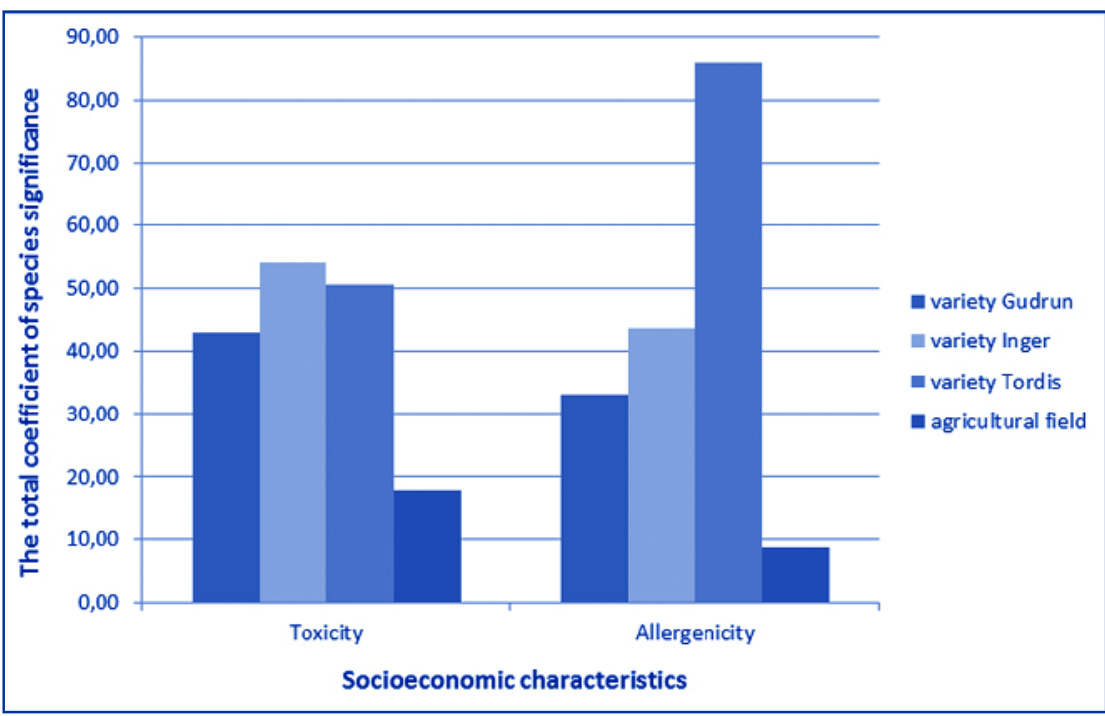

Figure 2 Socio-economic importance of characteristics that reduce ecosystem utility

increase of the feed importance was caused mostly due to the occurrence of perennial grass Agropyron repens in the Tordis understorey, with high positive eco-value for feed potential, its maximal persistence (44 times from 44 carried surveys) and high abundance (mean: $5.57 \% \pm$ SE: 1.13) during the two years of our research. Half of understorey of the variety Gudrun consisted from plant species with feed potential (18 plants), however their feed importance was the lowest from the observed willow varieties (only 31.76). The understorey of the variety Inger consisted from the same number of plants with positive feed potential like the understorey of farmers, nutritionists, chemists, marketers or physicians (Jurko, 1990). SRC willow may constitute an important resource for bees, even under the stress of the harvest cycle, and recommendations are given for improving the biodiversity aspect. There are many flowering plants, but not all can be harvested by honey bees, because of their physiognomy (Reddersen, 2001). In apiculture, a plant is classified as melliferous if it can be harvested by honey bees (Ayansola and Davies, 2012). However, according to Stefan and Bodescu (2008), one third of the total melliferous resources in an area is the share of the bee families consumption, the rest being consumed by other insects. In the case of therapeutic or feed importance of surveyed understoreys as well as in the case of melliferous importance, the understorey of the variety Tordis was characterized by the highest importance (265.87). From the total species number present in the Tordis understorey, $77.78 \%$ had the melliferous potential (28 plant species). The Inger understorey was also characterized by the high melliferous importance (234.27) and also by the high percentage of melliferous plant species present in the understorey $(74.19 \%)$. The lowest melliferous importance was found in the understorey of the variety Gudrun (97.37) which was approximately by $60 \%$ lower compared with the other surveyed energy varieties. Gudrun understorey represented 18 plants with melliferous potential, i.e. $60 \%$ of total species number found there. Very low importance from melliferous point of view was found in adjacent agricultural field (7.38) where only $39.13 \%$ plant species were characterized by various melliferous potential ( 9 melliferous plant species). All these importance values represent only theoretical situation of all plants of understorey that can occur if all understorey plants blossom out.

Many wild growing plants produce toxins (alkaloids, glycosides, toxalbumins, photosensitizing substances, volatile oils, resins) and allergens (Dutkiewicz et al., 2001; Bergmann et al., 2012). According to Fehér et al. (2014), the herb undergrowth of energy plantations can be potentially dangerous for 
humans. Our results showed that the highest percentage of plant species containing toxins was found in agricultural field $(43.48 \%)$, what was represented by 10 plant species with specific toxic potential. Due to low abundance and frequency of occurrence (persistence) of adjacent plant species there, the total toxic importance was low as well (17.93). From the all surveyed willow varieties, the most species rich variety was also the richest one for plant species with various toxic potential. Thus, understorey of the variety Tordis consisted of 14 plant species with toxic potential which were characterized by the second highest toxic importance from all surveyed willow varieties (50.66). The same number of toxic plant species was contained in understoreys of the varieties Inger and Gudrun (9 plant species) that also formed the similar percentage of the total species number found in their understoreys (Inger: 29.03\%; Gudrun: 30.00\%). The highest toxic importance was recorded in the Inger understorey (54.01), the lowest in the Gudrun understorey (42.86) (Figure 2).

With the enhanced consciousness of health, research on allergenic pollen plants receives increased concerns. A mass of allergenic pollen plants is centralized in urban areas (Jianan et al., 2004; Bergmann et al., 2012). In general, SRC plantations are often grown near urban or rural areas, therefore there are some apprehensions that pollens of SRC tree varieties or many plants they contain may cause pollinosis in sensitive individuals. Obtaining data regarding pollen is necessary because exposure to allergenic pollen is an increasing public health problem in occidental societies where pollinosis has become widespread (D'Amato et al., 2007; Heguy et al., 2008). Our data showed that understoreys of energy willow varieties consisted also of plants with allergenic potential. The Tordis understorey consisted of the highest amount of allergenic plants (14 plants) which represented $38.89 \%$ of total species found in the Tordis experimental plot. Also, the allergenic importance of its understorey was the highest one (85.94) from the observed willow varieties. The Gudrun understorey consisted of $36.67 \%$ of allergenic plants (11 plants), but allergenic importance of its understorey (33.14) was lower than in the Inger understorey (43.53) where we found lower percentage of allergenic plants (29.03\%; 9 plants with allergenic potential). The percentage of allergenic plants in the adjacent agricultural field was similar to what we found in the Inger or the Gudrun understorey (30.43\%). The allergenic importance of agricultural field was only 8.70 (Figure 2), however, $77 \%$ of this value appertained to Amaranthus retroflexus (recorded only in the agricultural field) whose pollen is a common cause of respiratory allergy in many countries, for instance reported in Wurzen et al. (1995), Tehrani et al. (2010) or Villalba et al. (2014).

\section{Conclusions}

The rate of understorey to provide selected utility functions depended on the planted crop. The variety Tordis was characterized by the highest socio-economic importance of characteristics enhancing ecosystem utility. All surveyed varieties demonstrated higher melliferous, therapeutic and feed importance of their understoreys, and thus they can be assumed to be the better option for contribution to the total socio-economic value of a region than agricultural field. Agricultural field did not enhance the allergenicity and toxicity levels to such an extent as understorey of willow energy varieties. Because of the highest potential of the variety Tordis to enhance the allergenicity level of human settlements and the highest potential of the variety Inger to become the source of toxic plants and reduce the socioeconomic value of surrounding agroecosystems or affect human health, we recommend their cultivation outside of human settlements.

\section{Acknowledgment}

This paper was supported by the VEGA grant no. 1/0942/12 Variety dependence of production and energetic potential of fast growing woody plants of genus Salix and Populus in the first and second three-years harvest cycles and energetic grass Miscanthus in agroclimatic conditions of Southwestern Slovakia and grant no. 1/1220/12 Modelling of growth of perennial grasses growing on climatic conditions of southern Slovakia.

\section{References}

AYANSOLA, A.A. - DAVIES, B.A. 2012. Honeybee floral resources in Southwestern Nigeria. In Journal of Biology and Life Science, vol. 3, 2012, no. 1, pp. 127-139.

BAUM, S. - WEIH, M. - BUSCH, G. - KROIHER, F. - BOLTE, A. 2009. The impact of short rotation coppice plantations on phytodiversity. In Landbauforschung - vTI Agriculture and Forestry Research, vol. 59, 2009, no. 3, pp. 163-170.

BERGMANN, K. CH. - ZUBERBIER, T. - AUGUSTIN, J. - MüCKE, H. G. - STRAFF, W. 2012. Climate change and pollen allergy: cities and municipalities should take people suffering from pollen allergy into account when planting in public spaces. In Allergo Journal, vol. 2, 2012, no. 21, pp. 103-107.

BERNDES, G. - HANSSON, J. 2007. Bioenergy expansion in the EU: Cost-effective climate change mitigation, employment creation and reduced dependency on imported fuels. In Energy Policy, vol. 35, 2007, no. 12, pp. 5965-5979.

BRAUN-BLANQUET, J. 1964. Pflanzensoziology : Grundzüge der Vegetationskunde. Wien : Springer-Verlag, 1964.

BRITT, C.P. - FOWBERT, J. - McMILLAN, S.D. 2007. The ground flora and invertebrate fauna of hybrid poplar plantations : results of ecological monitoring in the PAMUCEAF project. In Aspect Applied Biology, vol. 82, 2007, no. 1, pp. 83-90.

D'AMATO, G. - CECCHI, L. - BONINI, S. - NUNES, C. - ANNESIMAESANO, I. - BEHRENDT, H. - LICCARDI, G. - POPOV, T. - VAN CAUWENBERGE, P. 2007. Allergenic pollen and pollen allergy in Europe. In Allergy, vol. 62, 2007, no. 9, pp. 976-990.

DAILY, G.C. 1997. Introduction: What are Ecosystem Services? In DAILY, G.C. Nature's Services: Societal Dependence on Natural Ecosystems. Washington, D.C. : Island Press, 1997, pp. 1-12. ISBN 978-1559634762.

DUTKIEWICZ, J. - SULLIVAN, J.B. - SELTZER, J. 2001. Biological hazards, biotoxins and toxigenic fungi. In SULLIVAN, J.B. - KRIEGER, G.R. (eds). Clinical environmental health and toxic exposures. Philadelphia : Lippincott Williams \& Wilkins, 2001, pp. 1022-1046. ISBN 978-0683080278.

EEA. 2013. EU bioenergy potential from a resource-efficiency perspective. Luxembourg : Publications Office of the European Union, EEA Report, 2013, no. 6. ISBN 978-92-9213-397-9.

ELIÁŠ, P. 2010. From vegetation functions to ecosystem services. In Životné prostredie, vol. 44, 2010, no. 2, pp. 59-64 (in Slovak). 
FEHÉR, A. - HALMOVÁ, D. - KONČEKOVÁ, L. 2014. Evaluation of biodiversity of ground flora in short rotation coppice: positive and negative externalities. In $22^{\text {nd }}$ European Biomass Conference and Exhibition. Hamburg, Germany, 2014, pp. 342-345.

FRY, D. - SLATER, F. 2009. The biodiversity of short rotation willow coppice in the Welsh landscape. In Prifysgol Aberystwyth University [online], [Retrieved 2013-11-16]. Retrieved from: http://www.aber. ac.uk/en/media/departmental/ibers/research/willowforwales/ Biodiversity-of-src-coppice-in-the-Welsh-Landscape.pdf

HAUPTVOGL, M. 2011. Effect of soil-climate and hydrological conditions in Southwestern Slovakia on the selected indicators of productivity of fast growing tree genera Salix : dissertation thesis. Nitra: SUA, 2011. 118 p. (in Slovak).

HEGUY, L. - GARNEAU, M. - GOLDBERG, M.S. - RAPHOZ, M. - GUAY, F. - VALOIS, M.F. 2008. Associations between grass and weed pollen and emergency department visits for asthma among children in Montreal. In Environmental Research, vol. 106, 2008, no. 2, pp. 203-211.

JALOTA, R.K. - SANGHA, K.K. - KOHLI, R.K. 2000. Under-storey vegetation of forest plantations in N-W India - An ecological economic assessment. In Journal of Tropical Medicinal Plants, vol. 1, 2000, no. 1/2, pp. 115-124.

JIANAN, X. - ZHIYUN, O. - HUA, Z. - XIAOKE, W. - HONG, M. 2007. Allergenic pollen plants and their influential factors in urban areas. In Acta Ecologica Sinica, vol. 27, 2007, no. 9, pp. 3820-3827.

JURKO, A. 1990. Ecological and socio-economic evaluation of vegetation. Bratislava : Príroda, 1990. ISBN 80-07-00391-6.

KÖHN, J. 2009. Socio-economics in SRC - a review on concepts and the need for transdisciplinary research. In Landbauforschung - vTI Agriculture and Forestry Research, vol. 59, 2009, no. 3, pp. 223-232. LAPIN, M. - FAŠKO, P. - MELO, M. - ŠŤASTNÝ, P. - TOMLAIN, J. 2002. Climate (in Slovak). In Atlas SR. Bratislava: MŽP SR, 2002.

LEVY, L.A. - BABU, S. - HAMILTON, K. 2005. Ecosystem conditions and human well-being. In HASSAN, R. M. - SCHOLES, R. - ASH, $\mathrm{N}$. Ecosystems and human well-being: Current state and trends: Findings of the condition and trends working group. Washington DC : Island Press, pp. 123-140. ISBN 1-55963-228-3.

LINKEŠ, V. - PESTÚN, V. - DŽATKO, M. 1997. Guide for using maps of the valued soil-ecological unit. Bratislava : Výskumný ústav pôdnej úrodnosti. ISBN 80-85361-19-1 (in Slovak).

MA. 2005. Ecosystems and human well-being: biodiversity synthesis. Washington DC : World Resources Institute. ISBN 1-56973-588-3.

MARHOLD, K. - HINDÁK, F. (eds.). 1998. Checklist of non-vascular and vascular plants of Slovakia. Bratislava : VEDA. ISBN 80-224-0526-4.

MOSQUERA-LOSADA, M.R - MORENO, G. - PARDINI, A. - MCADAM, J.H. - PAPANASTASIS, V. - BURGESS, P.J. - LAMERSDORF, N. - CASTRO, M. - LIAGRE, F. - RIGUEIRO-RODRÍGUEZ, A. 2012. Past, present and future of agroforestry systems in Europe. In RAMACHANDRAN NAIR, P.K. - GARRITY, D. (eds) Agroforestry - The future of global land use. London : Springer, pp. 285-312. ISBN 978-94-007-4675-6.
REDDERSEN, J. 2001. SRC-willow (Salix viminalis) as a resource for flower-visiting insects. In Biomass \& Bioenergy, vol. 20, no. 3, pp. 171-179.

RÖSCH, CH. - AUST, C. - JÖRRISSEN, J. 2013. Envisioning the sustainability of the production of short rotation coppice on grassland. In Energy, Sustainability and Society, vol. 3, no. 7, pp. $1-17$.

SANGHA, K.K. - JALOTA, R.K. 2005. Value of ecological services of exotic Eucalyptus tereticornis and native Dalbergia sissoo tree plantations of North-Western India. In Conservation and Society, vol. 3, no. 1, pp. 92-109.

SHMI. 2013. Information about climatic conditions of area Kolíňany [email]. Message for: Michal BENIAK. 2013-12-08 [Retrieved 201309-09]. Personal communication.

STEFAN, G. - BODESCU, D. 2008. The melliferous potential quantification. In Lucrări Ştiinţifice - seria Agronomie, vol. 51, no. 1, pp. 443-448.

ŠPÁNIK, F. - ŠIŠKA, B. - TOMLAIN, J. 2000. Indicators of agroclimatic regionalization of agricultural production in Slovakia in terms of climate change. Bratislava : Slovenská bioklimatická spoločnost SAV. ISBN 80-7137-855-0 (in Slovak).

TEHRANI, M. - SANKIAN, M. - ASSAREHZADEGAN, M.A. - FALAK, R. JABBARI, F. - VARASTEH, A. 2010. Immunochemical characterization of Amaranthus retroflexus pollen extract: extensive cross-reactive allergenic components among the four species of Amaranthaceae/ Chenopodiaceae. In Iran Journal of Allergy, Asthma and Immunology, vol. 9, no. 2, pp. 87-95.

TILMAN, D. - KNOPS, J. - WEDIN, D. - REICH, P. - RITCHIE, M. SIEMANN, E. 1997.The influence of functional diversity and composition on ecosystem processes. In Science, vol. 277, no. 5330, pp. 1300-1302.

VILLALBA, M. - BARDERAS, R. - MAS, S. - COLÁS, C. - BATANERO, E. - RODRÍGUEZ, R. 2014. Amaranthaceae Pollens: Review of an emerging allergy in the mediterranean area. In Journal of Investigational Allergology and Clinical Immunology, vol. 24, no. 6, pp. 371-381.

WEIH, M. - DIMITRIOU, I. 2012. Environmental impacts of short rotation coppice (SRC) grown for biomass on agricultural land. In BioEnergy Research, vol. 5, no. 3, pp. 535-536.

WEIH, M. - KARACIC, A. - MUNKERT, H. - VERWIJST, T. - DIEKMANN, M. 2003. Influence of young poplar stands on floristic diversity in agricultural landscapes (Sweden). In Basic and Applied Ecology, vol. 4, no. 2, pp. 149-156.

WURZEN, P.A. - NELSON, H.S. - LØWENSTEIN, H. - IPSEN, H. 1995. Characterization of Chenopodiales (Amaranthus retroflexus, Chenopodium album, Kochia scoparia, Salsola pestifer) pollen allergens. In Allergy, vol. 50, no. 6, pp. 489-497. 